\section{MicrotensileBond Strength of Adhesive Systems in Different Dentin Regions on a Class II Cavity Configuration}

\author{
Mário Alexandre Coelho Sinhoreti ${ }^{1}$, Eveline Freitas Soares ${ }^{1}$, Gabriel Flores \\ Abuna ${ }^{1}$, Lourenço Correr-Sobrinho ${ }^{1}$, Jean-François Roulet ${ }^{2}$, Saulo Geraldeli²
}

\author{
'Department of Restorative \\ Dentistry, Dental Materials \\ Division, Piracicaba Dental School, \\ UNICAMP - Universidade de \\ Campinas, Piracicaba, SP, Brazil \\ ${ }^{2}$ Department of Restorative \\ Dental Sciences, Division of \\ Operative Dentistry, College \\ of Dentistry, University of \\ Florida, Gainesville, FL, USA
}

Correspondence: Mário Alexandre Coelho Sinhoreti, Avenida Limeira, 901, 13414-903 Piracicaba, SP, Brasil. Tel: +55-19-2106-5200. e-mail: sinhoreti@fop.unicamp.br

Key Words: dentin, adhesive, acid-etching, composite resin.

\section{Introduction}

Modern restorative dentistry relies broadly on bonding the restorative materials to the tooth hard tissues. Because of that, dentin bonding has been the focus in research field for the last twenty years (1). Since dentin is an anisotropic substrate, bond strength achieved in the adhesive layer connecting restorative materials and dentin structure is affected by dentin tubules orientation, tubule densities and the proportion of intratubular and intertubular dentin $(2,3)$.

It is known that these tubules are originated from odontoblast cell tracks from dentin-enamel junction (DEJ) or cementum to pulp chamber (2). Each one of these dentin tubules has a varying radius and an almost straight or slightly wave-like pattern, which penetrates into dentin (4). In its central axis, dentin tubules are approximately parallel in the root part of the tooth, but are obviously radial in the peripheral crown region (4).

Nowadays, this dentin arrangement is still explored through new approaches including different image exams (3), in which it was observed that right beneath enamel (approximately $0.3 \mathrm{~mm}$ ) an extensive tubule tilting, supposedly because of odontoblast cell crowding, was detected, which relocates itself in its orthogonal path in the same manner as above the pulp chamber (3).
Besides tubule orientation, tubules density also plays an important role in bond strength (3). Close to DEJ, tubule density is much lower (occupying just 1\% of the total surface area) and with a smaller diameter $(0.8 \mu \mathrm{m})$. While closer to pulp chamber, tubule density is much higher (occupying approximately $22 \%$ of the total surface area) and with a larger diameter $(2.5 \mu \mathrm{m})(2)$. Since there are fewer tubules in the periphery of dentin area, there is an enormous variation between peritubular volume percentage from proximal to central dentin area (2). In the outer area, the amount of peritubular dentin is much reduced, while in central dentin, it may predominate in a thicker size (5).

Peritubular dentin is characterized by a more mineralized and homogeneous substrate compared to intertubular dentin and it is also essentially collagen-free containing mostly apatite crystals (5). While intertubular dentin as a dominant structure in proximal dentin, separates tubules and it is composed of a matrix of type I collagen supported by apatite (5). This proportion along with intrinsic characteristics of peritubular and intertubular dentin, added to the already described differences of tubule orientations, often passes unnoticed during experimental 
projects (6).

On the other side of bonding strength from current adhesive systems, two different approaches are the most frequently used in an attempt to obtain a reliable dentin bonding. The etch-and-rinse technique adhesive systems rely on the removal of the smear layer and exposure of the collagen matrix by acid etching, followed by the application of a primer solution and a bond adhesive or a prime-bonding agent, which combines primer and adhesive resin into one single solution (7). The second approach remains on the use of self-etching primers, in which acid and primer solutions are present in two different bottles or combined in a single one (8). This has its bonding mechanism based upon the simultaneous etching, priming and bonding to the smearcovered dental tissue, reducing the number of steps for the adhesive procedure, shortening the application time and leading to a lower sensitivity technique (8).

The efficacy of adhesive systems is regularly evaluated in vitro by their ability to bond to coronal dentin, usually making use of flat surfaces (6). This neglects many clinical realities, since higher $\mathrm{C}$-factor increases polymerization contraction stresses over tooth-composite interface. This results from a reduction of the composite property of relaxation after light-curing is carried out, introducing plastic deformations that are susceptible to resin degradation. Besides this, it is possible to find dentinal tubules with different orientations on these dentin flat surfaces, due to their radial distribution in relation to the pulp chamber. This structural anisotropy implies that the nature of dentin substrate usually presented for bonding procedure also varies among different locations prompting discrepancies in often encountered bond strengths (2).

Most microtensile bond strength ( $\mu \mathrm{TBS}$ ) studies use flat dentin surfaces where composite blocks are built in increments. In this case, the C-factor (9) can be considered low, differently from what occurs in class I and class II configuration cavities. Thus, this study evaluated the effect of the orientation of dentin tubules in pulpal wall of a class II cavity on $\mu$ TBS test of two etch-and-rinse and two self-etching adhesives. The null hypotheses tested were as follows: 1) the different orientations of the dentin tubules would have no effect on $\mu$ TBS values and 2) the different types of adhesives would not influence on $\mu$ TBS.

\section{Materials and Methods}

\section{Tooth Preparation}

Twenty four human third molars extracted for therapeutic reasons were donated under Ethics Committee approval (protocol \# IRB 201500060, College of Dentistry, UF). They were certificated as sound molars and the gross debris were removed. The teeth were stored in distilled water at $4{ }^{\circ} \mathrm{C}$ for utilization within six months.
Twenty teeth $(n=20)$ had their top occlusal enamel surface and roots sectioned perpendicular to its long axis using a diamond disc (EXTEC Corporation, Enfield, CT, USA) attached to a low-speed cutting machine (Isomet 1000, Buehler Ltda., Lake Bluff, IL, USA) under water cooling. Roots were sectioned $2 \mathrm{~mm}$ below the cementoenamel junction and the pulp tissue was removed (Fig. 1A). After that, coronal pulp chamber filling restoration was performed using Clearfil SE Bond adhesive system (Kuraray Medical Inc., Tokyo, Japan) and Filtek Z250 flowable composite (3M ESPE, St. Paul, MN, USA) applied according to manufacturer's instructions (Table 1). Each sectioned tooth was glued with a cianocrylate instant adhesive (Loctite Super Glue, Westlake, $\mathrm{OH}, \mathrm{USA}$ ) on a polyvinyl chloride (PVC) stub pre-filled with self-curing acrylic resin (Opti-Cryl, Guarne, Colombia) until the bond strength test was performed (Fig. 1B).

A class II cavity configuration (mesial-oclusal-distal, MOD) was simulated in a simplified manner, excluding mesial and distal boxes on each tooth, using a mechanical preparation machine (Elquip, São Carlos, SP, Brazil). For that, a high-speed hand piece (Kavo, Joinville, SC, Brazil) with a diamond bur 3097 (KG Sorensen, Cotia, SP, Brazil) was positioned at $90^{\circ}$ to tooth long axis and a cavity configuration $4 \mathrm{~mm}$ wide by approximate $3 \mathrm{~mm}$ deep (Fig. 1C) was performed under water cooling until middle dentin was fully exposed.

\section{Bonding Procedure}

Teeth were randomly divided into four groups corresponding to a different type of adhesive system applied according to manufacturers' recommendations (Table 1).

Group SBMP - Dentin ( $n=5)$ : surface was acid etched

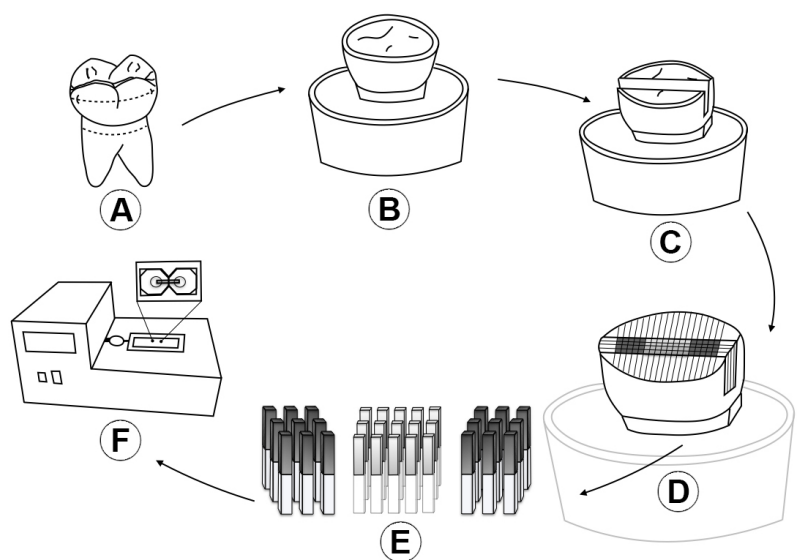

Figure 1. Schematic illustration of extracted tooth before enamel and root removal (A); Sample fixation on PVC stub pre-filled with acrylic-resin (B); Class II (MOD) $4 \mathrm{~mm}$ wide x $3 \mathrm{~mm}$ deep cavity configuration (C); Composite restoration by incremental technique (D); Beam shape samples acquired from proxima 1 and central dentin location (E); Microtensile bond strength test, $\mu$ TBS (F). 
using phosphoric acid 35\% (3M ESPE) for 15s, rinsed for 15 s and gently dried with absorbent pads until excess humidity was removed. Scotchbond Multi Purpose adhesive system, (3M ESPE) was applied. First primer solution was actively spread for $15 \mathrm{~s}$ using a disposable brush (Microbrush; Vigodent, Rio de Janeiro, RJ, Brazil) and gently air dried for $5 \mathrm{~s}$, followed by adhesive application.

Group OPFL - Dentin ( $n=5)$ : surface was acid etched as in group SBMP, primer solution was spread actively for $15 \mathrm{~s}$ and air dried for $5 \mathrm{~s}$, followed by Optibond FL (Kerr Corporation, Orange, CA, USA) adhesive application.

Group CSE - Primer solution was applied for $20 \mathrm{~s}$ on dentin surface $(n=5)$ and mild air dried for $5 \mathrm{~s}$ before adhesive Clearfil SE Bond (Kuraray) was applied.

Group OPXTR - Primer solution was applied actively for $20 s$ on dentin surface $(n=5)$ and mild air dried for 5 $s$ before bond adhesive Optibond XTR (Kerr Corporation), was applied for $15 \mathrm{~s}$ and air dried for $5 \mathrm{~s}$.

The procedure of light curing was carried out for the adhesive layer of each group for $10 \mathrm{~s}$ using a LED light curing unit (Bluephase G2, Ivoclar Vivadent, Liechtenstein) in all samples, with a $1,392 \mathrm{~mW} / \mathrm{cm}^{2}$ irradiance. A composite $\dot{\sigma}$ restoration was performed in two horizontal increments, where each layer was light cured for $20 \mathrm{~s}$ using the same light curing unit. Samples were stored for $24 \mathrm{~h}$ at $37^{\circ} \mathrm{C}$ in distilled water.

\section{Microtensile Bond Strength ( $\mu$ TBS) Test}

Each sample was sectioned in mesial-distal and buccallingual directions in perpendicular way to its bonding interface (Fig. 1D) using a diamond disc coupled to a low-speed cutting machine under water cooling at 250 rpm. Samples obtained (Fig. 1E) were beam shaped with at most $1 \mathrm{~mm}^{2}$ adhesive area measured with a digital caliper (Mitutoyo Corporation, Tokyo, Japan).

Beams from the same sample were divided into two subgroups according to dentin location from where they were removed. In central dentin group (CD), specimens were located in the middle area of dentin exposed surface, corresponding to the interspace of pulp horns. In proximal dentin group (PD), specimens were located in distal and mesial area of dentin surface. Enamel specimens or specimens presenting defects such as lack of material or irregularities were discarded (Fig. 1D).

After $24 \mathrm{~h}$ storage at $37^{\circ} \mathrm{C}$ in distilled water, specimens were positioned and glued with cyanoacrylate glue (Zapit, Corona, CA, USA) into Geraldeli's jig-2 for $\mu$ TBS test (Fig. 1F) at $0.5 \mathrm{~mm} / \mathrm{min}$ speed in a universal testing machine (OMT100, Odeme Dental Research, Luzerna, SC, Brazil). Final values were express in $\mathrm{MPa}$ obtained from the following

Table 1. Materials, manufacturers, abbreviations, compositions and application procedures

\begin{tabular}{|c|c|c|c|}
\hline Material & $\begin{array}{l}\text { Adhesive system, } \\
\text { manufacturer } \\
\text { and abbreviation }\end{array}$ & Composition & Application procedure \\
\hline \multirow{2}{*}{$\begin{array}{l}\text { Etch-and- } \\
\text { rinse } 3 \text { steps } \\
\text { adhesive } \\
\text { systems }\end{array}$} & $\begin{array}{l}\text { Scotchbond MP, } \\
\text { 3M-ESPE; SBMP }\end{array}$ & $\begin{array}{l}\text { Primer: HEMA, water, polyalkenoic acid } \\
\text { copolymer, water; Bond: BisGMA, HEMA, CQ }\end{array}$ & $\begin{array}{l}\text { Application of etchant }\left(\mathrm{H}_{3} \mathrm{PO}_{4}\right) \text { for } 15 \mathrm{~s} \text {, water } \\
\text { rinse for } 15 \mathrm{~s} \text {, gently air dry. Application of } \\
\text { primer for } 15 \mathrm{~s} \text {, gently air volatilization for } 5 \mathrm{~s} \text {. } \\
\text { Application of adhesive, light cure for } 10 \mathrm{~s} \text {. }\end{array}$ \\
\hline & $\begin{array}{l}\text { Optibond } \\
\text { FL, Kerr; } \\
\text { OPFL }\end{array}$ & $\begin{array}{l}\text { Primer: HEMA, ethanol, GPDM, MMEP, } \\
\text { water, CQ, BHT Bond: TEGDMA, } \\
\text { UDMA, GDMA, HEMA, Bis-GMA, filler, } \\
\text { CQ, approximately 48wt\% filled }\end{array}$ & $\begin{array}{l}\text { Application the etchant }\left(\mathrm{H}_{3} \mathrm{PO}_{4}\right) \text { for } 15 \mathrm{~s} \text {, water } \\
\text { rinse for } 15 \mathrm{~s} \text {, gently air dry, application of primer } \\
\text { actively for } 15 \mathrm{~s} \text {, gently air volatilization for } 5 \mathrm{~s} \text {. } \\
\text { Application of adhesive, light cure for } 10 \mathrm{~s} \text {. }\end{array}$ \\
\hline \multirow{2}{*}{$\begin{array}{l}\text { Self-etching } \\
\text { 2-step } \\
\text { adhesive } \\
\text { systems }\end{array}$} & $\begin{array}{l}\text { Clearfil SE, } \\
\text { Kuraray; CSE }\end{array}$ & $\begin{array}{l}\text { Primer: 10-MDP, HEMA, hydrophilic } \\
\text { dimetachylate, CQ, accelerators, water; } \\
\text { Bond: 10-MDP, Bis-GMA, HEMA, } \\
\text { hydrophilic dimethaclylate, colloidal } \\
\text { silica, CQ, initiators, accelerators }\end{array}$ & $\begin{array}{l}\text { Application of primer for } 20 \mathrm{~s} \text {, gently air volatilization } \\
\text { for } 5 \mathrm{~s} \text {, application of adhesive and light cure for } 10 \mathrm{~s} \text {. }\end{array}$ \\
\hline & $\begin{array}{l}\text { Optibond XTR, } \\
\text { Kerr; OPXTR }\end{array}$ & $\begin{array}{l}\text { Primer: GPDM, hydrophilic co-monomers, } \\
\text { water, ethanol, acetone Bond: resin } \\
\text { monomers, HEMA, inorganic fillers, ethanol }\end{array}$ & $\begin{array}{l}\text { Application of primer actively for } 20 \mathrm{~s} \text {, } \\
\text { gently air volatilization for } 5 \mathrm{~s} \text {, application } \\
\text { of adhesive for } 15 \mathrm{~s} \text {, light-cure for } 10 \mathrm{~s} \text {. }\end{array}$ \\
\hline $\begin{array}{l}\text { Microhybrid } \\
\text { restorative } \\
\text { filler }\end{array}$ & $\begin{array}{l}\text { Filtek Z } 250 \\
\text { (A2), 3M-ESPE }\end{array}$ & Bis-EMA, TEGDMA, UDMA, zirconium, silica & $\begin{array}{l}\text { Composite placement through incremental technique } \\
\text { with each layer light-cured for } 20 \text { s using a LED } \\
\text { light curing unit (Bluephase G2, Ivoclar). }\end{array}$ \\
\hline Etchant & $\mathrm{H}_{3} \mathrm{PO}_{4}$ & $\begin{array}{l}\text { Amorphous silica-thickened } \\
\text { 35\% phosphoric acid gel }\end{array}$ & $\begin{array}{c}\text { Dentin surface was acid etched using phosphoric } \\
\text { acid 35\% (3M ESPE) for } 15 \mathrm{~s} \text {, rinsed for } 15 \\
\text { s and dried using absorbent pads. }\end{array}$ \\
\hline
\end{tabular}

Abbreviations: 10-MDP, 10-methacryloyloxydecyl dihydrogen phosphate; BHT, butylhydroxytoluene; Bis-GMA, bisphenol A diglycidyl methacrylate; CQ, camphorquinone; GDMA, glycerol dimethacrylate; GPDM, glycerol phosphate dimethacrylate; HEMA, 2-hydroxyl methacrylate; MMEP, mono-2-methacryloyloxyethylphthalate; UDMA, diurethane dimethacrylate. 
equation: $\mu \mathrm{TBS}=\mathrm{F} / \mathrm{A} \times 0,098$; In which, $\mu \mathrm{TBS}$ stands for microtensile bond strength value (MPa), $\mathrm{F}$ for microtensile force applied for the test (kgf) and A the sample bonded area $\left(\mathrm{mm}^{2}\right) / 100=\left(\mathrm{cm}^{2}\right)$. $\mu$ TBS results from each area (CD or PD) were employed as the average of the tested beams for each adhesive system (SBMP, OPFL, CSE and OPXTR) tested.

Failure mode was classified by observing each fractured beam under stereomicroscope ( 50 x, Nikon, model SMZ-1B, Tokyo Japan). The failure mode was classified in adhesive, cohesive, mixed/dentin or mixed/resin type of failure.

\section{Scanning Electronic Microscopy}

The same above described rocedure was conducted to restore extra representative samples $(n=4)$ from each adhesive group in central and proximal dentin locations for scanning electron microscopy (SEM) observation. Samples were sectioned in 2-mm-thick slices with a double sided diamond saw and embedded in epoxy resin (Buehler epoxycure resin and hardener, Agar Scientific Elektron Technology, Stansted, UK). After 24 h curing time, the mounted stubs were finished with silicon carbide sandpaper in ascending granulations (\#600-2500, Norton Saint-Gobain, Guarulhos, SP, Brazil) and polished by felt pads with diamond grinding polishing pastes ( $6 \mu \mathrm{m}$ to 0.25 $\mu \mathrm{m}$, Ted-Pella Inc., Redding, CA, USA). Phosphoric acid at $50 \%$ was applied during $5 \mathrm{~s}$, rinsed and silica-dried for 2 h. A sputter-coating with gold-palladium for $60 \mathrm{~s}$ at 45 $\mathrm{mA}$ in a vacuum metalizing chamber (MED 010; Balzers, Liechtenstein) was applied before observation by SEM (LEO 435 VP; Carl Zeiss, Jena, Germany), operated under 20 kV in different magnifications.

\section{Statistical Analysis}

The $\mu$ TBS mean of the beams in each specimen region was calculated. Data were transformed according to square root $(x+0)$ and submitted to one-way ANOVA with splitplot arrangement and Tukey's test for pairwise comparison $(\alpha=0.05)$. The factor (parcel) considered was material and dentin regions in two levels (central and proximal), as

Table 2. Microtensile bond strength mean $( \pm \mathrm{SD})$ values (MPa) for self-etching and etch-and-rinse adhesives in central and proximal dentin locations ( $p>0.05$ ).

\begin{tabular}{lcc}
\hline Adhesives & Central dentin & Proximal dentin \\
\hline CSE & $29.1 \pm(5.9) \mathrm{aA}$ & $27.1 \pm(6.3) \mathrm{aA}$ \\
OPXTR & $29.6 \pm(6.1) \mathrm{aA}$ & $28.0 \pm(4.8) \mathrm{aA}$ \\
SBMP & $30.5 \pm(4.7) \mathrm{aA}$ & $23.2 \pm(5.2) \mathrm{bB}$ \\
OPFL & $29.3 \pm(5.5) \mathrm{aA}$ & $22.0 \pm(6.2) \mathrm{bB}$ \\
\hline
\end{tabular}

Different uppercase letters in the row and lowercase letters in the columns mean statistical significance $(\alpha=0.05)$. sub-factor (sub-parcel).

\section{Results}

The pre-testing failures (CSE - 1 central and 1 proximal; OPXTR - 1 central and 1 proximal; SBMP - 3 proximal and OPFL - 2 central and 4 proximal) were not included in the statistical analysis. For $\mu$ TBS test results (Table 2), there were no statistically significant differences among etch-andrinse adhesives (SBMP 30.5 MPa and OPFL 29.3 MPa) and self-etching adhesives (CSE 29.1 MPa and OPXTR 29.6 MPa) on central dentin location (Table $2, p>0.05$ ). When tested on proximal dentin location, etch-and-rinse adhesives (SBMP 23.2 MPa and OPFL 22.0 MPa) obtained statistically lower $\mu$ TBS test values compared do self-etching adhesives (CSE - 27.1 MPa and OPXTR 28.1 MPa, $\mathrm{p}<0.05$ ). For all groups, mixed type failure pattern was more frequently observed, except for SBMP in central dentin area, which presented more often adhesive type of failure. Self-etching adhesive systems (CSE and OPXTR) presented generally mixed/resin type of failure, while etch-and-rinse adhesive systems presented generally mixed/dentin type of failure (Fig. 2).

\section{SEM Observation}

SEM images illustrated dentin tubules closer to a parallel position with tooth long axis in central dentin location (Fig. 3A), while in proximal dentin location (Fig. 3B), a tilted angulation was observed. From an occlusal dentin surface perspective, the same pattern could be observed in central dentin (Fig. 3C) and in proximal dentin (Fig. 3D). Lateral diffusion of resin tags (Fig. 3E) and odontoblast processes (Fig. 3F) could be observed by greater magnifications up from approximately $7 \mathrm{kx}$.

\section{Discussion}

In theory, the bond strength achieved by any dentin bonding agent at any dentin depth is simply correlated with

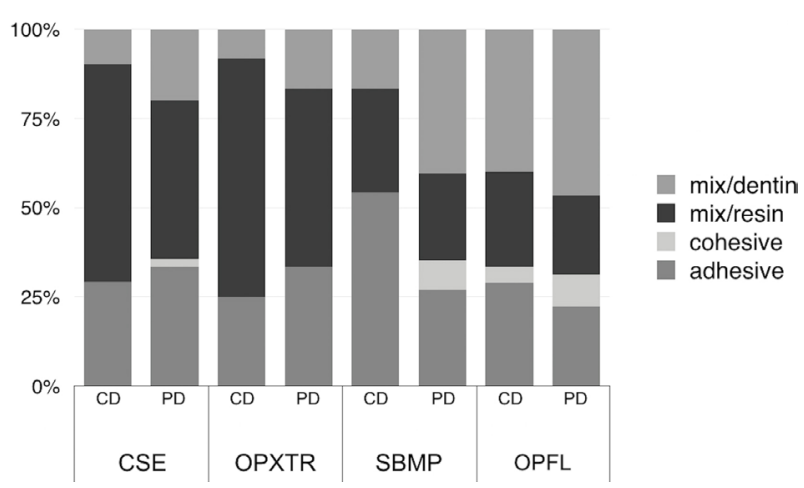

Figure 2. Failure modes analysis of debonded specimens (\%) after $\mu$ TBS test. 


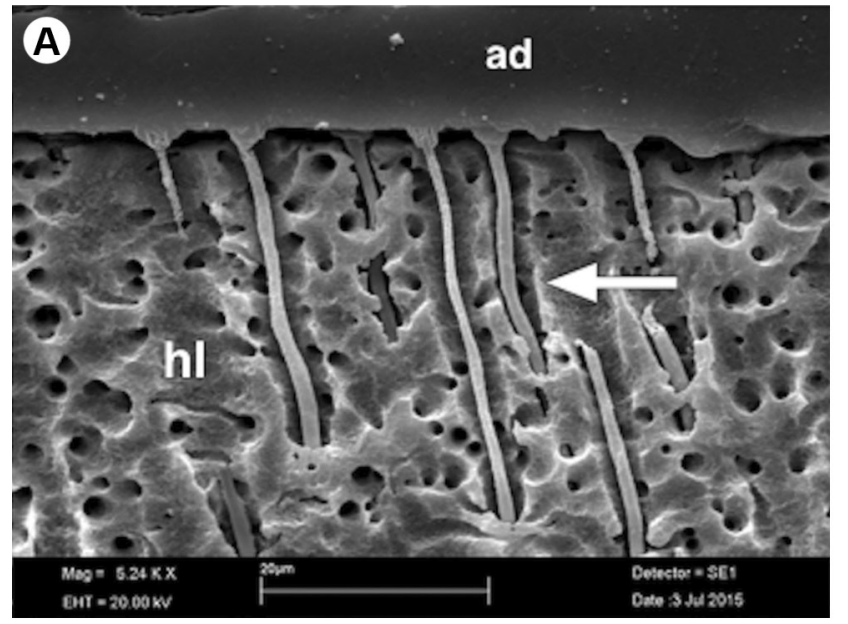

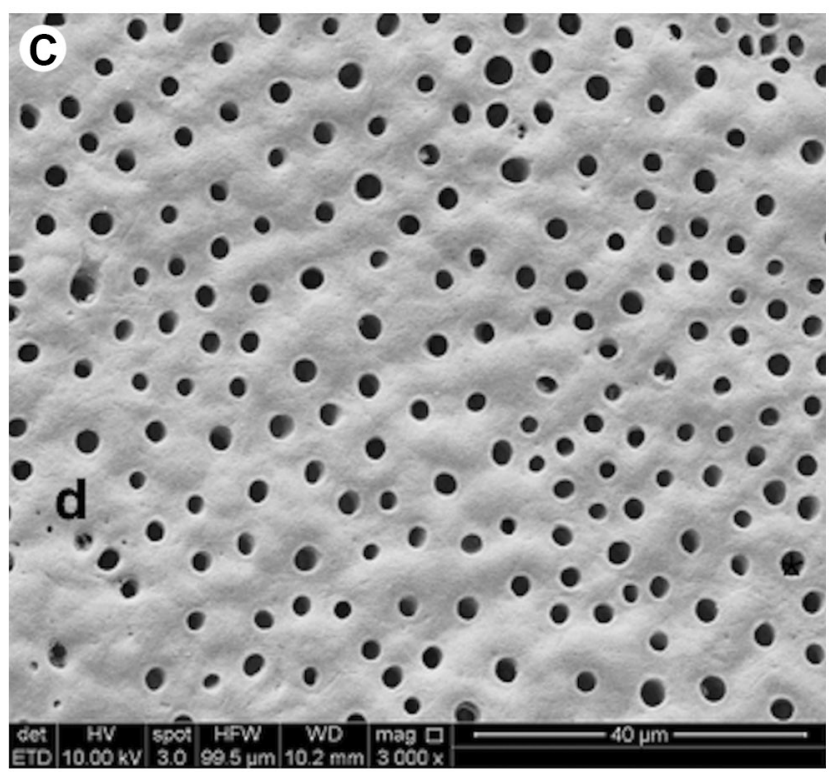

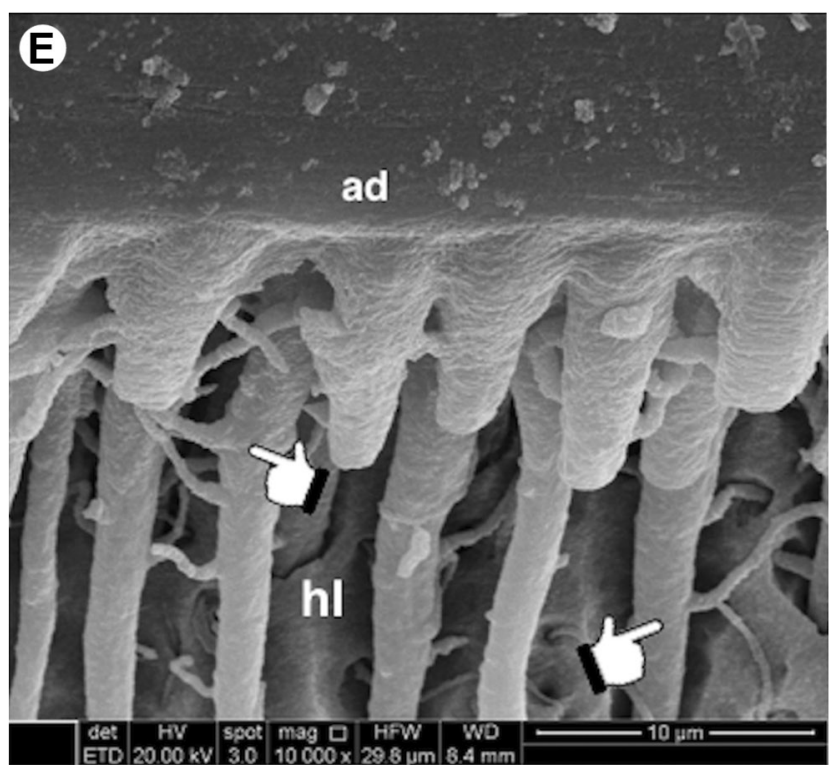

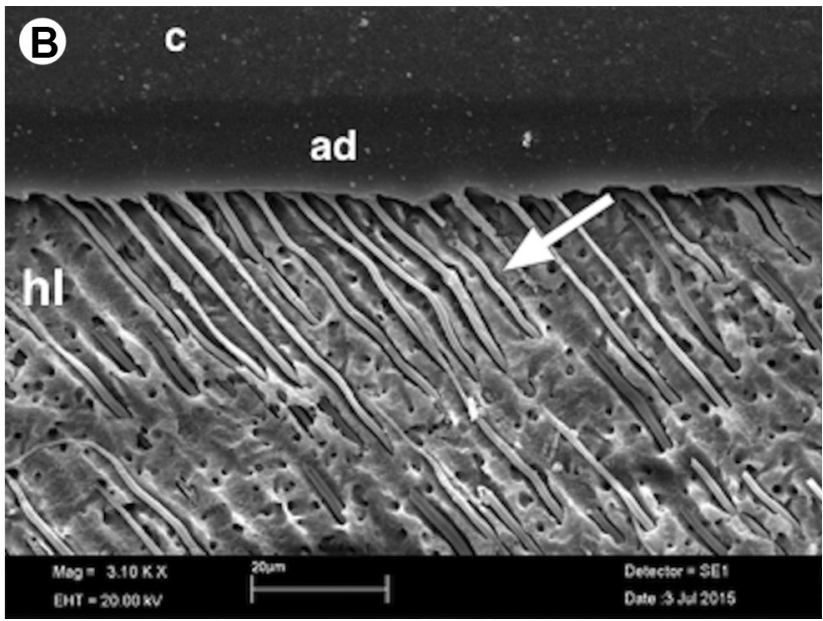
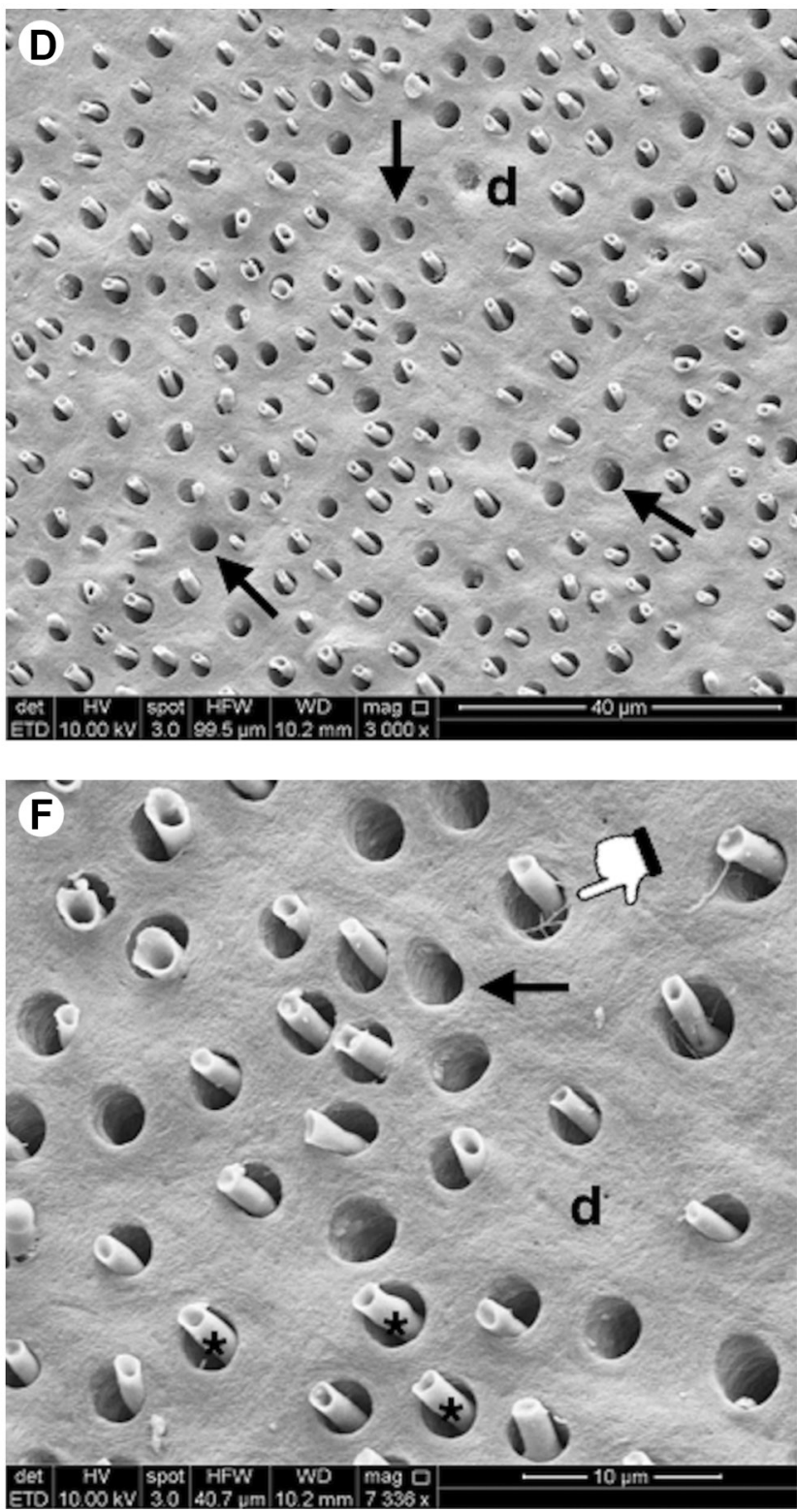

Figure 3. SEM images of dentin samples regarding hybrid layer formation in different locations. c. Composite; ad. Adhesive; hl. hybrid layer; d. Dentin. (A) and (C) - central dentin location; (B) and (D) - proximal dentin location; (E) shows rich lateral diffusion of resin tags; (F) corresponds to occlusion view of dentin tubules from proximal dentin. Highlighting: "white arrows" point to dentin tubules filled with resin tags in different angulations; "black arrows" point to tilted dentin tubules lumen from an occlusal perspective; "Handpoint" showing lateral tags diffusion in proximal dentin. $\left({ }^{*}\right)$ Odontoblast processes. 
three aspects: the area available for surface adhesion, the area occupied by resin tags and the area of intertubular dentin infiltrated by resin adhesives (10). In reality, differences in dentin substrate as dentin depth $(11,12)$, mineral content (2), morphology (3), age (11), disease (4), wetness (2). Contemporaneity of adhesive approaches and compositions $(13,14)$ gives this subject a more complex perspective. Beyond these matters, in laboratories, flat dentin surfaces are mostly used for $\mu$ TBS tests. In this case, not only different dentin morphologies are neglected, but a low C-factor is present (9), which contributes to impairing a proper reproduction of many clinical conditions.

In this study, $\mu$ TBS test was conducted comparing central and proximal (mesial and distal) dentin using etch-andrinse or self-etching bonding agents applied in a class II (mesial-occlusal-distal, C-factor $\cong 2.5$ ) cavity configuration prepared in order to obtain a more pragmatic clinical situation. In this context, smear layer was produced with diamond burs to result in a denser precipitate also towards a clinical reality. Among the results, proximal and central dentin subtracts were compared, in which self-etching adhesives presented no statistical differences among all tested groups, contrarily to other studies $(13,15)$. SBMP and OPFL etch-and-rinse adhesive systems presented lower $\mu \mathrm{TBS}$ values in proximal dentin compared to central dentin. This led us to a partial acceptation of the first hypothesis, since $\mu$ TBS values were affected by different dentin tubules orientations, but only for etch-and-rinse adhesive systems in proximal dentin area.

This possibly occurred due a non-uniform hybrid layer formation, since in this cavity configuration, proximal dentin enclosed a substrate close to DEJ corresponding to tilted angle tubules and tubules from cusps correlative areas due the tubules' dentin radial distribution. Under cusps, tubules tend to tilt in a slight "S" shape (4) differing lightly in angle orientation and position from the outer dentin area and the region above pulp chamber (3), as may be seen in dentin microscopy (Fig. 3A, B, C and D). Even though the resin tags could be observed in all groups through SEM confirming a hybrid layer formation, this dentin anisotropy characteristic possibly jeopardized adhesive and substrate intimate contact for SBMP and OPFL, interfering in the arrangement of an uniform hybrid layer (2). This may be the reason for a greater mixed/dentin type of failure (Fig. 2) observed these groups for proximal dentin (Fig. 3B and D). It may also lead to a clinical warning, because of the risk of leaving unsealed a residual dentin structure, with chances to cause post-operative sensitivity, bacterial microleakage, marginal staining and/or secondary caries (16).

Besides that, proximal dentin in the class II configuration prepared in this study encompasses majority of intertubular dentin, a lower dentin tubules density and a higher amount of lateral branches from main dentin tubules $(4,10)$ pointing these characteristics as important elements for bonding strength in this area. Frequently, higher bond strength values are presented closer to DEJ in a so called superficial dentin $(13,17)$. However, in this study, proximal dentin areas presented lower statistical $\mu$ TBS values for etch-and-rinse adhesives, which rises some interesting points. Intertubular micromechanical resin impregnation may be uncertain from adhesion steps such as acid etching demineralization followed by primer and resin diffusion for etch-and-rinse adhesives. This resin tags infiltration via radial diffusion constitutes lateral branches and ramifications from the main lumen contributing substantially to bond strength as can be seen in Figure 3 ( $E$ and F). However, they also may compromise $\mu$ TBS values if the acid etching followed by resin penetration does not succeed evenly, as possibly occurred to etch-and-rinse adhesive systems in proximal dentin.

About dentin substrate in the proximal at last, there is reduced intrinsic moisture $(5,18)$, resulting in a two perspectives situation for bond strength. The first is about moisture control, providing enough humidity to prevent shrinkage of demineralized dentin and consequently keeping the exposed collagen scaffold structured for resin diffusion after acid etching demineralization (19). The second is to not exceed the necessary amount of water, avoiding the dilution of some adhesive monomers and phase separation, leading to an improper functionality $(14,19)$. In this case, the self-etching technique has the advantage of a more adaptable approach depending of the intrinsic subtract re-moisture $(8,13,20)$.

As part of this behavior, self-etching hydrophilic commercial blends are formulated to change the smear layer with acidic monomers rather than remove it, creating a permeable membrane by smear layer and smear plugs $(20,8)$. This contributed to $\mu$ TBS results in this study, as there were no statistically significant differences between each other in central and proximal dentin, and still presented higher $\mu$ TBS values compared to etch-and-rinse adhesives systems in proximal dentin. This standard behavior in different dentin locations presented by self-etching adhesives contrasted with SBMP and OPFL results, leading to a partial acceptance of the second hypothesis, as different types of adhesives did influence the $\mu$ TBS values for proximal dentin region only. This highlights recent self-etching adhesive systems to be less influenced by different dentin anisotropic characteristics $(21,22)$.

Both self-etching adhesives applied in this study are considered mild types $(\mathrm{pH} \approx 2.0)(14,23)$, what contributes to open its path through smear layer in a more balanced manner, preventing an overwhelming dentin wetness rise, especially in central dentin area (perpendicular to tubule 
orientation and closer to pulp chamber). In this way, such behavior includes overcoming smear layer and dentin buffering capacity but still maintaining enough monomer concentration to intersect water successfully (20). This surely reflected in a more even hybrid layer formation by dentin intrinsic differences (Fig.3) and bond strength performance (Table 2).

Furthermore, CSE also demineralize dentin incompletely, leaving hydroxyapatite remains attached to collagen structure accessible for chemical bonding with 10MDP (10-methacryloyloxydecyl dihydrogenphosphate) functional monomer (Table 1) by the adhesion/ decalcification concept (20) resulting in a low-sensitivity technique (8). OPXTR has acetone as solvent in its chemical composition, appealing to a highly hydrophilic volatile component, capable of removing quickly the water and evaporates leaving a further higher concentration of monomers as glycerol phosphate dimethacrylate (GPDM) for resin penetration (24). It also contributed to the lack of statistical differences between self-etching adhesives groups in various dentin locations.

With this, adhesive systems approaches and their $\vec{s}$ chemical compositions seem to remain as key elements for the challenges of dentin anisotropy characteristics, in agreement with some other studies (21). For these purposes, different distributions of the tested groups can be articulated, as for an example, radial distribution of groups from a middle region of central dentin (25). Further studies are required for a more precise clinical reproduction in reliable laboratory conditions in order to follow dentin anatomy and contribute to resin restorations durability pursuit.

It may be concluded that in class II type cavity configuration, dentin location influenced bond strength of etch-and-rinse adhesive systems. In proximal dentin, etch-and-rinse adhesive systems presented lower bond strength results. Self-etching adhesive systems presented homogeneous bond strength values in proximal and central dentin region.

\section{Resumo}

0 objetivo deste estudo foi avaliar a resistência de união à microtração ( $\mu$ TBS) de sistemas adesivos auto-condicionantes e convencionais comparados por entre diferentes regiões dentinárias (central-DC ou proximal-DP) em um preparo cavitário classe II. Um preparo cavitário classe II (mesio-ocluso-distal) foi simulado em 20 terceiros molares humanos (4 $\mathrm{mm}$ largura/3 $\mathrm{mm}$ profundidade). Adesivos convencionais (Scotchbond Multi Purpose, $n=5$, SBMP e Optibond $F L, n=5$, OPFL) e adesivos autocondicionantes (Clearfil SE Bond, $n=5$, CSE e Optibond XTR, $n=5$, OPXTR foram aplicados. As restaurações classe II foram realizadas usando a técnica incremental e fotoativadas (Bluephase/G2). As amostras foram seccionadas em forma de palito ( $1 \mathrm{~mm}^{2}$ secção transversal), posicionadas no dispositivo de Geraldeli para o teste $\mu$ TBS (velocidade transversal de $0,5 \mathrm{~mm} / \mathrm{min}$ ). 0 padrão de fratura foi analisado em estereoscópio e classificado em coesivo-resina, adesivo, misto/resina, misto/dentina.
Amostras $(n=4)$ foram preparadas para observação em microscópio eletrônico de varredura. Os dados foram submetidos a ANOVA um fator e teste de Turkey $(\alpha=0,05)$. Não houve diferença estatística significante entre SBMP, OPFL, CSE, e OPXTR em DC $(p>0,05)$. Entretanto, para SBMPe OPFL em DP, valores $\mu$ TBS foram significativamente menores comparados com CSE e OPXTR $(p<0,05)$. Em todos os grupos, o padrão de fratura misto foi o mais frequentemente observado, exceto em SBMP/CD (adesivo). Em um preparo classe II, a localização da DP influenciou negativamente a resistência de união de sistemas adesivos convencionais. Oposto aos adesivos auto-condicionantes, que em DP apresentaram valores de resistência de união maiores comparados com adesivos convencionais.

\section{Acknowledgments}

The authors are thankful to CAPES and FAPESP (Proc. \#2014/11301-4) scholarship support, EW Kitajima and RB Salaroli for SEM equipment support in the "NAP/MEPA/ESALQ/USP" (Piracicaba, SP, Brazil), to J Bettini, E Teixeira Neto and CAO Ramirez for FEI Quanta 650 FEG support in the Brazilian Nanotechnology National Laboratory (LNNano, CNPEM, Campinas, SP, Brazil).

\section{References}

1. Amaral CM, Correa D de S, Miragaya LM, Silva EM. Influence of organic acids from the oral biofilm on the bond strength of self-etch adhesives to dentin. Braz Dent J 2015;26:497-502.

2. Marshall GW Jr., Marshall SJ, Kinney JH, Balooch M. The dentin substrate: structure and properties related to bonding. J Dent 1997;25:441-458.

3. Zaslansky P, Zabler S, Fratzl P. 3D variations in human crown dentin tubule orientation: A phase-contrast microtomography study. Dent Mater 2010;26:e1-e10.

4. Nanci A. Ten Cate's oral histology: development, structure and function. 6th ed. St. Louis: Mosby; 2003.

5. Tjaderhane L, Carrilho MR, Breschi L, Tay FR, Pashley DH. Dentin basic structure and composition - an overview. Endodontic Topics 2012;20:3-29.

6. Carneiro KK, Meier MM, Santos CC, Maciel AP, Carvalho CN, Bauer J. Adhesives doped with bioactive niobophosphate micro-filler: degree of conversion and microtensile bond strength. Braz Dent J 2016;27:705711.

7. Gan J, Liu S, Zhou L, Wang Y, Guo J, Huang C. Effect of ND:YAG laser irradiation pretreatment on the long-term bond strength of etch-andrinse adhesive to dentin. Oper Dent 2017;42:62-72.

8. Giannini M, Makishi P, Ayres AP, Vermelho PM, Fronza BM, Nikaido T, et al.. Self-etch adhesive systems: a literature review. Braz Dent J 2015;26:3-10.

9. Feilzer AJ, De Gee AJ, Davidson CL. Setting stress in composite resin in relation to configuration of the restoration. J Dent Res 1987;66:16361639.

10. Toledano M, Osorio R, Ceballos L, Fuentes MV, Fernandes CA, Tay FR et al.. Microtensile bond strength of several adhesive systems to different dentin depths. Am J Dent 2003;16:292-298.

11. Burrow MF, Takakura H, Nakajima M, Inai N, Tagami J, Takatsu T. The influence of age and depth of dentin on bonding. Dent Mater 1994;10:241-246.

12. Lopes $M B$, Sinhoreti MA, Gonini Júnior $A$, Consani $S, M c C a b e$ JF. Comparative study of tubular diameter and quantity for human and bovine dentin at different depths. Braz Dent J 2009;20:279-283.

13. Pegado REF, Amaral FLB, Flório FM, Basting RT. Effect of different bonding strategies on adhesion to deep and superficial permanent dentin. Eur J Dent 2010;4:110-117.

14. Van Landuyt KL, Snauwaert J, De Munck J, Peumans J, Yoshida Y, Poitevin A, et al.. Systematic review of the chemical composition of contemporary dental adhesives. Biomaterials 2007;28;3757-3785.

15. De Munck J, Mine A, Cardoso MV, Neves AA, Van Landuyt KL, Poitevin $A$, et al.. Effect of dentin location and long-term water storage on bonding effectiveness of dentin adhesives. Dent Mater 2011;30:7-13.

16. Fernández EM, Martin JA, Angel PA, Mjör IA, Gordan W, Moncada GA. 
Survival rate of sealed, refurbished and repaired defective restorations: 4-year follow-up. Braz Dent J 2011;22:134-139.

17. Foscaldo T, Dos Santos GB, Miragaya LM, Garcia M, Hass V, da Silva EM. Effect of HEMA phosphate as an alternative to phosphoric acid for dentin treatment prior to hybridization with etch-and-rinse adhesive systems. J Adhes Dent 2016;18:425-434.

18. Yoshikawa T, Sano H, Burrow MF, Tagamil J, Pashley DH. Effects of dentin depth and cavity configuration on bond strength. Dent Res 1999;78:898-905.

19. Pashley DH, Ciucchi B, Sano H, Horner JA. Permeability of dentine to adhesive agents. Quintessence Int 1992;24:618-633.

20. Van Meerbeek B, Yoshihara K, Yoshida Y, Mine A, De Munck J, Van Landuyt KL. State of the art of self-etch adhesives. Dent Mater 2011;27:17-28.

21. Marchesi G, Frassetto A, Visintini E, Diolosa M, Turco G, Salgarello S, et al.. Influence of ageing on self-etch adhesives: one-step vs. two-step systems. Eur J Oral Sci 2013;121:43-49.
22. Szesz A, Parreiras $S$, Reis $A$, Loguercio A. Selective enamel etching in cervical lesions for self-etch adhesives: A systematic review and metaanalysis. J Dent 2016;53:1-11.

23. Schiltz-Taing $M$, Wang $Y$, Brown BSD, Chen L. Effect of tubular orientation on the dentin bond strength of acidic self-etch adhesives. Oper Dent 2011;36:86-91.

24. Walter R, Swift EJ, Boushell LW, Braswell K. Enamel and dentin bond strengths of a new self-etch adhesive system. J Esthet Restor Dent 2011;23:390-398.

25. Geraldeli S, Perdigão J, Larson WK. A novel micro-tensile dentin bond strength method using paired dentin quarters. J Dent Res 2002;80:abstract 3373 